\title{
PENYEDIAAN SARANA CUCI TANGAN SEDERHANA UNTUK PENCEGAHAN PENYEBARAN COVID-19 DI PASAR GENTENG, SURADITA, CISAUK
}

\author{
Listya Utami Karmawan', Widya Agustinah", Renna Eliana Warjoto', \\ Daru Seto Bagus Anugrah ${ }^{1}$, Danniella Yudianti ${ }^{1}$, Illene Nanine ${ }^{1}$, dan \\ Eunice Catherine Witness ${ }^{1}$
}

\author{
${ }^{1}$ Fakultas Teknobiologi, Universitas Katolik Indonesia Atma Jaya, Jalan Jendral Sudirman no 51, Jakarta 12930 \\ Email: listya.utami@atmajaya.ac.id
}

\begin{abstract}
COVID-19, a source of distress in most countries, has encouraged world leaders to issue necessary policies to resolve this global pandemic. An alarming rate of infections in the community has pushed the Indonesian government to come up with the Large-Scale Social Restriction (Pembatasan Sosial Berskala Besar/PSBB). The faculty of Biotechnology of Atma Jaya Catholic University of Indonesia has since initiated a community service to halt the spread of COVID19 by supplying simple hand washing facilities around Pasar Genteng Traditional market in Suradita, Cisauk. Prior to the installations, the traditional market lacked proper sanitizing facilities. Clean water sources such as taps are commonly situated far away from the marketplace. Traders and visitors crowd these areas each day, exponentially increasing the risk of spreading COVID-19. The crowded populations of the traditional market are a motivating factor for this community service, which aims to increase the public awareness in the prevention of COVID-19. Activities of this community service includes installations of hand washing facilities along with educational infographics of proper sanitizing procedures. A total of 21 participants attended the community service while maintaining physical distancing conditions and were encouraged to use the hand wash facilities at the end of the service. The community service was successful, providing impactful benefits towards the traders and visitors, with a raised community awareness of the importance of personal hygiene. The facilities are well maintained after 4 weeks and exemplary community awareness is displayed from their initiative that showed from the monitoring and evaluation results.
\end{abstract}

keywords: cisauk, covid-19, community service, hand washing facility

\begin{abstract}
ABSTRAK
COVID-19, yang merupakan sumber penyebab keresahan berbagai negara di dunia telah menyebabkan pemerintah dunia mengeluarkan kebijakan untuk mengatasi pandemi yang terjadi secara global ini. Data di Indonesia menunjukkan angka terinfeksi yang terus meningkat sehingga pemerintah mengeluarkan kebijakan berupa Pembatasan Sosial Berskala Besar (PSBB). Oleh karena itu, Fakultas Teknobiologi Universitas Katolik Indonesia Atma Jaya berinisiatif melakukan kegiatan pengabdian masyarakat untuk menghambat tingkat penyebaran COVID19 melalui penyediaan sarana cuci tangan sederhana di Pasar Genteng. Pasar tradisional ini terletak di kompleks Suradita, Cisauk. Sebelum kegiatan pemasangan, pasar ini kekurangan fasilitas sanitasi yang layak. Sumber air bersih seperti air sumur terletak jauh dari pasar dan belum ada akses air ledeng. Setiap hari pedagang dan pengunjung memadati pasar sehingga meningkatkan risiko penyebaran COVID-19. Oleh karena itu, kegiatan pengabdian masyarakat ini difokuskan pada pembuatan dan pemasangan fasilitas cuci tangan sederhana yang dilengkapi dengan infografis tentang cara mencuci tangan yang benar serta pembagian masker kain. Serah terima perangkat cuci tangan dan acara pembukaan dihadiri oleh 21 orang peserta dengan tetap memperhatikan protokol kesehatan. Kegiatan pengabdian masyarakat melalui penyediaan sarana cuci tangan sederhana di Pasar Genteng, Cisauk telah berlangsung dengan baik dan dirasakan manfaatnya oleh para pedagang dan pengunjung pasar. Sarana cuci tangan sederhana ini diharapkan dapat meningkatkan kesadaran masyarakat tentang pentingnya menjaga kebersihan diri dalam rangka pencegahan penyebaran COVID-19. Sarana cuci tangan tersebut masih dalam kondisi baik setelah empat minggu dan kesadaran masyarakat juga cukup baik yang terlihat dari hasil monitoring dan evaluasi.
\end{abstract}

Kata Kunci: COVID-19, pasar tradisional, protokol kesehatan, sarana cuci tangan.

\section{PENDAHULUAN}

Saat ini infeksi COVID-19 di Indonesia masih meningkat. Data yang disosialisasikan melalui situs resmi www.covid19.go.id menunjukkan bahwa pada tanggal 27 April 2020 tercatat sejumlah 8.882 penduduk Indonesia yang diketahui positif terinfeksi COVID-19, 1.107 orang dinyatakan sembuh, dan 743 dinyatakan meninggal (Satgas Penanganan COVID-19, 2020). Pemerintah telah melakukan berbagai upaya untuk menekan laju penyebaran COVID-19 di Indonesia. Salah satunya 
melalui kebijakan Pembatasan Sosial Berskala Besar (PSBB) di wilayah-wilayah zona merah seperti Jabodetabek. Wilayah zona merah adalah wilayah dengan penyebaran pandemi yang hampir tidak terkendali, sehingga diperlukan upaya pengendalian seperti penangguhan kegiatan belajar-mengajar, ibadah, kegiatan bisnis yang melibatkan kerumunan orang, dan larangan mudik (Rizka, 2020), atau yang kita kenal dengan sebutan social/physical distancing. Selain itu, kebijakan PSBB juga membatasi perjalanan ke luar dan ke dalam wilayah yang dikenai kebijakan ini.

Masyarakat perlu mendukung berbagai upaya pemerintah dalam mencegah penyebaran COVID19 lebih lanjut. Dukungan yang dapat masyarakat lakukan antara lain mematuhi kebijakan PSBB dan berusaha meminimalkan potensi infeksi jika memang harus beraktivitas di luar rumah. Seperti yang direkomendasikan oleh World Health Organization (WHO) dan Center for Disease Control and Prevention (CDC), beberapa cara dapat dilakukan seperti menggunakan masker meskipun tidak merasa sakit, mencuci tangan secara teratur menggunakan sabun di bawah air mengalir selama minimum 20 detik, dan tidak menyentuh wajah dengan tangan (CDC, 2020; WHO, 2020.).

Sebagai bentuk kepedulian dan dukungan terhadap upaya pencegahan penyebaran COVID-19, Fakultas Teknobiologi Universitas Katolik Indonesia Atma Jaya telah melakukan kegiatan pengabdian masyarakat, yaitu melalui penyediaan sarana cuci tangan sederhana. Sasaran masyarakat untuk kegiatan ini adalah para pedagang dan pengunjung Pasar Genteng, yaitu pasar tradisional yang ada di kompleks Suradita, Cisauk. Setelah diperiksa, pasar ini berlokasi tidak memiliki sumber air bersih yang dapat diakses umum dengan mudah dan sangat minim akan sarana sanitasi yang layak, sementara kondisi pasar yang ramai oleh pengunjung pasar dapat meningkatkan resiko penyebaran COVID-19. Sejumlah kecamatan pada Kabupaten Tangerang Selatan per tanggal 28 Maret 2020 dinyatakan masuk ke dalam zona merah COVID-19, meliputi Kecamatan Cisauk (Joniansyah, 2020). Hal inilah yang mendorong Fakultas Teknobiologi Universitas Katolik Indonesia Atma Jaya untuk melakukan kegiatan pengabdian masyarakat yang berlokasi di Pasar Genteng, Suradita ini.

\section{METODE PELAKSANAAN PKM}

Kegiatan ini diawali dengan melakukan diskusi awal dengan tokoh masyarakat meliputi ketua RT setempat dan pihak pengelola pasar. Selanjutnya setelah disepakati, dilakukan pembuatan cuci tangan sederhana serta pemasangan infografis tentang cara mencuci tangan yang benar. Pemasangan sarana cuci tangan dan infografis dilakukan oleh tim dibantu dengan pemuda aktivis setempat. Kegiatan serah terima dan pemasangan sarana cuci tangan sederhana tersebut dilaksanakan pada hari Sabtu, tanggal 6 Juni 2020. Selanjutnya dilakukan edukasi cara mencuci tangan yang benar dipandu oleh fasilitator dengan alat bantu infografis (Gambar 1) yang ditempel pada sarana cuci tangan agar mudah dilihat. Perangkat cuci tangan sederhana diletakkan di pintu masuk Pasar Genteng, Suradita, Cisauk. Selain itu dilakukan pembagian masker kain dan kuesioner yang dibagikan kepada para pedagang dan pengunjung di pasar tersebut terkait keseringan pemakaian, tingkat kepuasan, penilaian kondisi sarana serta kritik dan saran.

Kegiatan monitoring pada sarana cuci tangan yang telah terpasang dilakukan empat minggu kemudian untuk memberikan evaluasi terhadap penggunaan sarana cuci tangan tersebut. Monitoring dan evaluasi dilaksanakan melalui wawancara dan pengisian kuesioner terhadap 20 orang responden yang terdiri atas 10 pedagang pasar, 8 pengunjung pasar, 1 ketua RT, dan 1 pengelola pasar dengan komposisi seperti yang ditunjukkan pada Gambar 3. Evaluasi khusus terhadap kondisi sarana cuci tangan yang telah terpasang dilakukan melalui wawancara dan pengisian kuesioner terhadap 5 orang perwakilan responden yang terdiri atas Ketua RT, 2 orang pedagang pasar, dan 2 orang pengunjung pasar secara acak. Formulir kuesioner dapat dilihat pada 
tautan https://forms.office.com/Pages/ResponsePage.aspx?id=ZlW0yvuRWUWVZ2jDlyP4sFxr TlaVgRHkTOwwf_T2BFUODIyR1U4M0I3MIRUMVQ1TEkwMjJFN1ZBMy4u

\section{Gambar 1}

Infografis Cara Mencuci Tangan Sesuai dengan World Health Organization (WHO 2020) yang Ditempelkan pada Drum Sarana Cuci Tangan

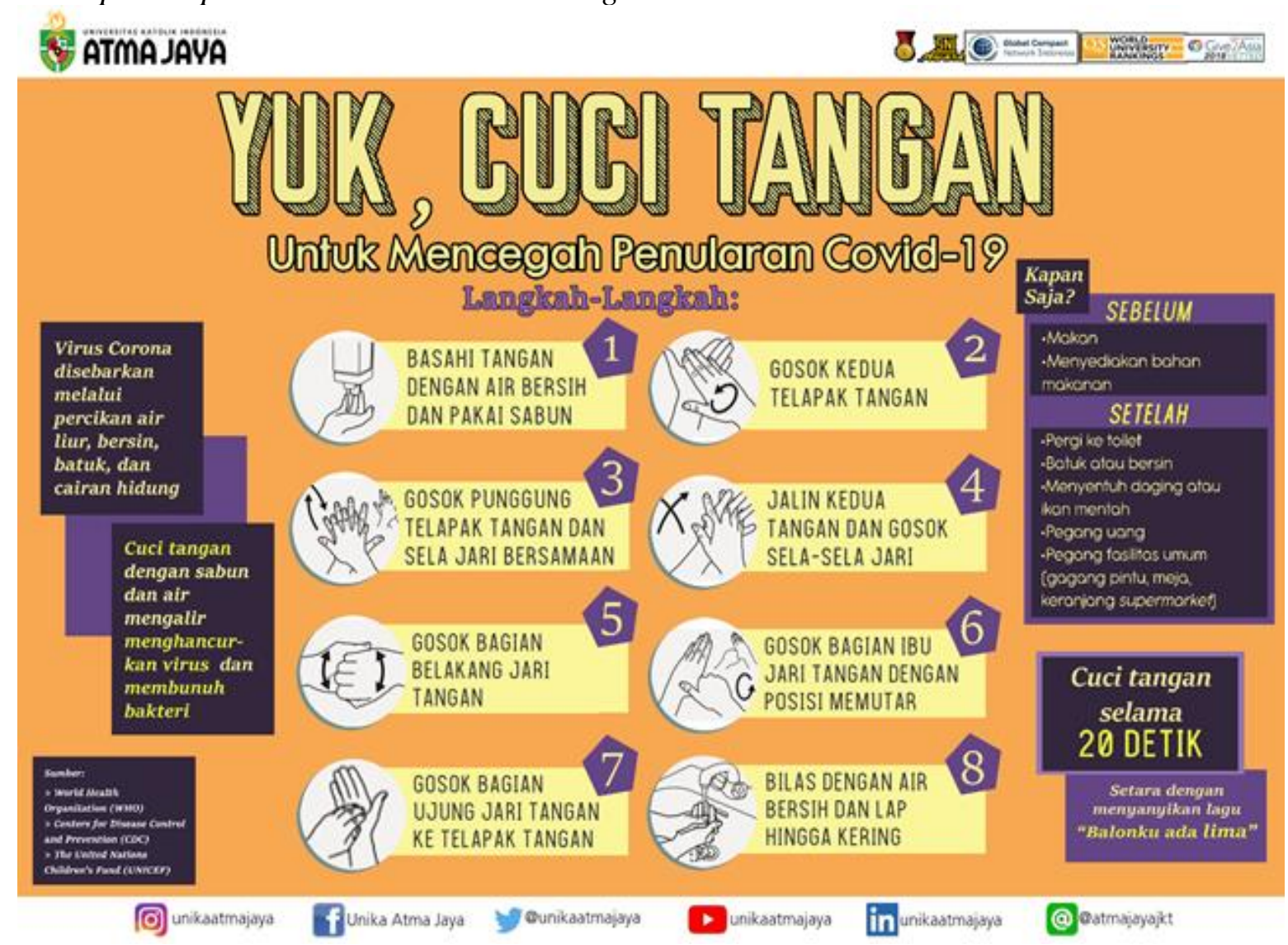

\section{HASIL DAN PEMBAHASAN}

Ketua RT dan pihak pengelola pasar menyambut baik inisiatif pemasangan sarana cuci tangan sederhana di Pasar Genteng. Berdasarkan wawancara dan survey di tempat diketahui bahwa Pasar Genteng tidak memiliki sarana cuci tangan publik. Umumnya kesadaran para pedagang maupun pengunjung akan pentingnya cuci tangan sebagai salah satu usaha pencegahan penyebaran COVID-19 masih rendah. Selain itu pasar masih sangat tradisional dan kebersihan belum terjaga dengan baik namun, di sisi lain warga setempat terbuka dan membuka diri untuk belajar membangun sarana penunjang kebersihan dari pihak lain yaitu Fakultas Teknobiologi Universitas Katolik Indonesia Atma Jaya. Dapat dilihat saat kegiatan pengabdian berlangsung, masyarakat setempat tergerak untuk membantu dalam proses pemasangan sarana cuci tangan.

Kegiatan pengabdian berjalan dengan lancar atas dukungan dari berbagai pihak (Gambar 2). Pedagang dan pengunjung pasar memperhatikan saat fasilitator mendemonstrasikan cara mencuci tangan selama 20 detik. Tidak ada lama mencuci tangan yang diketahui paling efektif, namun cuci tangan paling tidak 20 detik cukup untuk menghilangkan kotoran di tangan tanpa merusak kondisi tangan (CDC, 2020). Selain mencuci tangan selama 20 detik, sangat penting untuk menggunakan sabun ketika cuci tangan karena kandungan surfaktan seperti sodium laureth sulfate (LES) and sodium lauryl sulfate (SDS) dalam sabun akan meleburkan membran virus (Kawahara, et al., 2018). 
Fasilitator mengajak peserta yang terdiri atas pedagang dan pengunjung untuk menyanyikan lagu Balonku Ada Lima untuk membantu mempermudah perkiraan 20 detik mencuci tangan. Selama kegiatan serah terima dan edukasi, para pedagang dan pengunjung pasar menunjukkan antusiasme untuk langsung mencoba sarana cuci tangan sederhana (Gambar 3). Mereka juga dengan senang hati menerima masker kain yang dibagikan dan mencoba mengenakannya. Diketahui bahwa menurut WHO, transmisi COVID-19 dapat terjadi melalui kontak secara langsung maupun tidak secara langsung dengan orang yang terinfeksi, dapat diwujudkan melalui sekresi air liur dan sekresi saluran pernafasan atau droplet (WHO, 2020). Oleh karena itu penting sekali untuk memakai masker. Secara umum, masker kain memiliki efektivitas penyaringan di atas $50 \%$ (dari partikel $10 \mathrm{~nm}$ hingga $6 \mu \mathrm{m}$ ) sehingga cukup baik untuk mencegah infeksi. Efektivitas masker dapat ditingkatkan apabila menggunakan bahan kain yang lebih rapat jahitannya. Masker kain dapat digunakan berulang kali, tetapi harus dicuci bersih menggunakan sabun dan dibiarkan hingga kering sebelum digunakan kembali. (Chughtai, Seale, \& Macintyre, 2020; Konda et al., 2020). Selama kegiatan seluruh tim dan peserta berusaha mematuhi protokol kesehatan yang diwajibkan oleh pemerintah, yaitu selalu menggunakan masker dan menjaga physical distancing.

\section{Gambar 2}

\section{Serah Terima Sarana Cuci Tangan Disaksikan Oleh Warga Setempat}

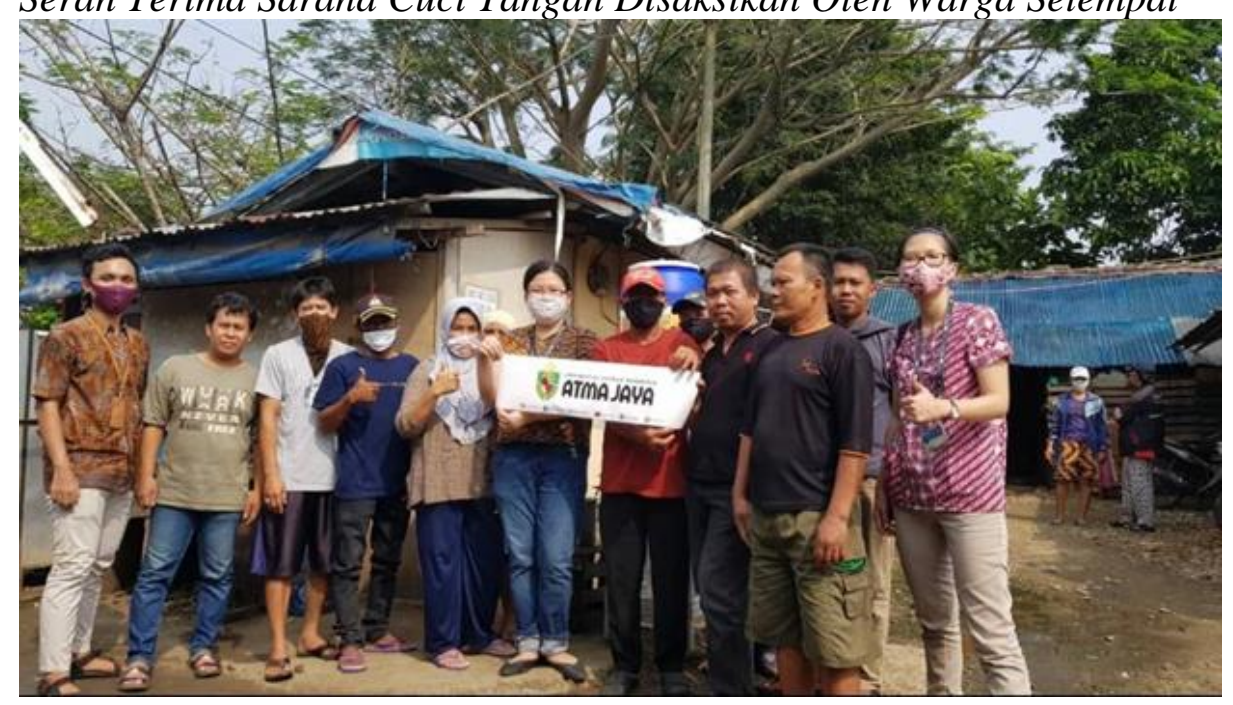

\section{Gambar 3}

Model Perangkat Cuci Tangan yang Disediakan Di Pasar Genteng, Cisauk

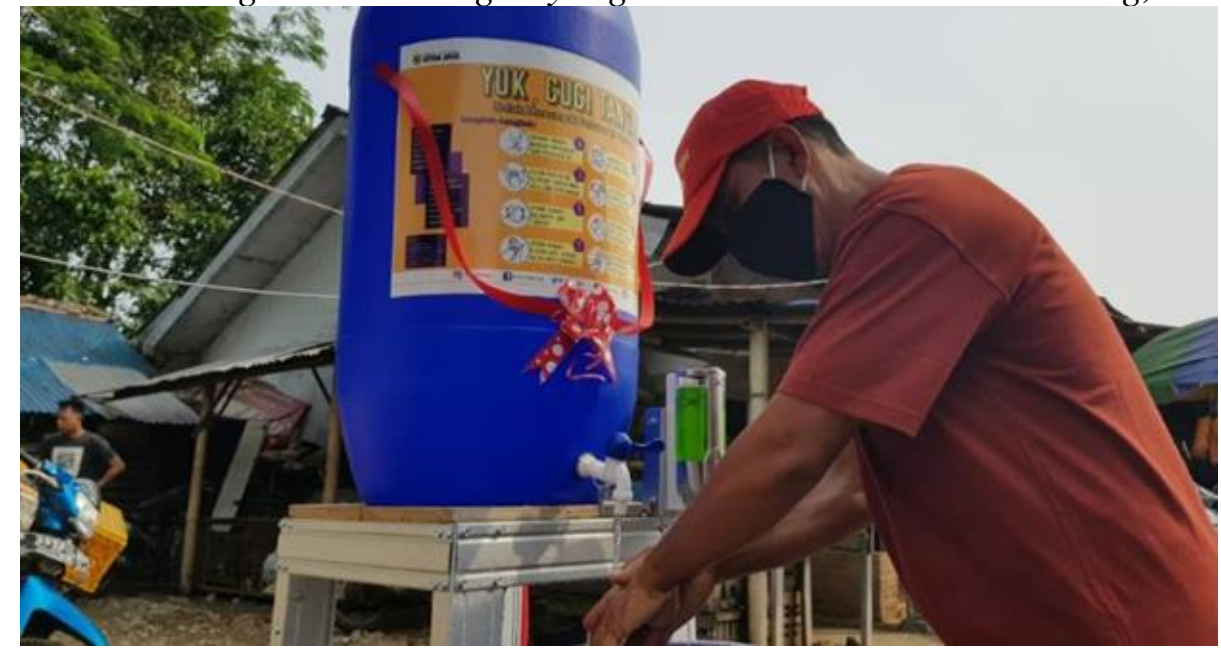


Pengisian kuesioner evaluasi dilakukan dengan metode wawancara terhadap 20 responden yang terdiri atas 10 pedagang pasar, 8 pengunjung pasar, 1 ketua RT, dan 1 pengelola pasar (Gambar 4). Data hasil wawancara menunjukkan bahwa sebanyak 7 responden sering menggunakan sarana cuci tangan tersebut dan responden lain hanya terkadang menggunakan sarana tersebut, sedangkan sisanya tidak pernah (Gambar 4). Mayoritas responden mencuci tangan dengan sarana tersebut sebelum masuk ke pasar dan saat mau pulang. Ada juga yang mencuci tangan setelah belanja dan memegang uang. Namun, hanya sedikit responden yang mencuci tangan sebelum dan setelah memegang daging mentah serta setelah dari toilet. Tidak ada responden yang mencuci tangan sebelum ke toilet. Banyak responden juga menggunakan sarana cuci tangan selain daripada situasi yang telah disebutkan (Gambar 5).

\section{Gambar 4}

Frekuensi Penggunaan Sarana Cuci Tangan (Kiri) dan Sebaran Profil Responden ( $n=20$, Kanan)
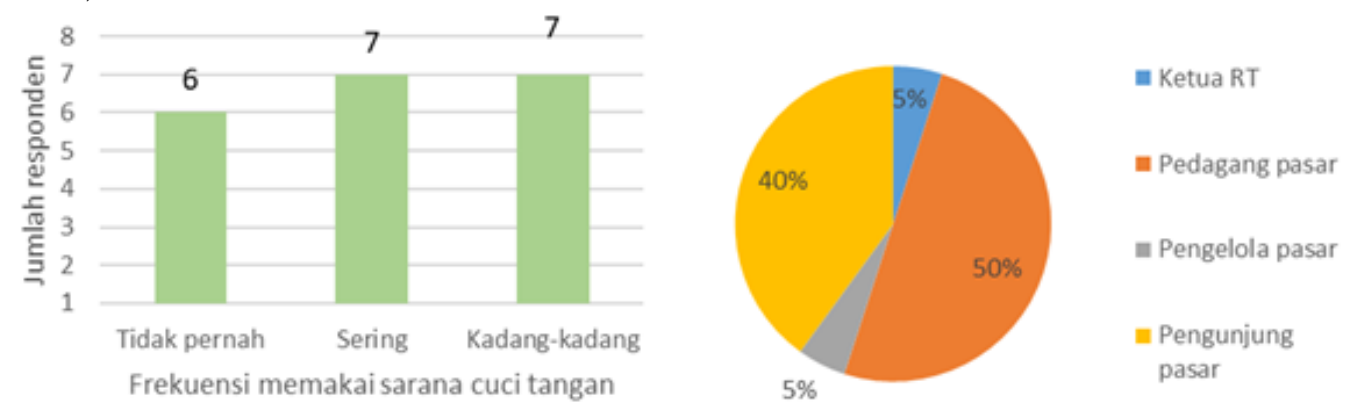

\section{Gambar 5}

Kebiasaan Responden Terhadap Waktu Penggunaan Sarana Cuci Tangan (n=20)

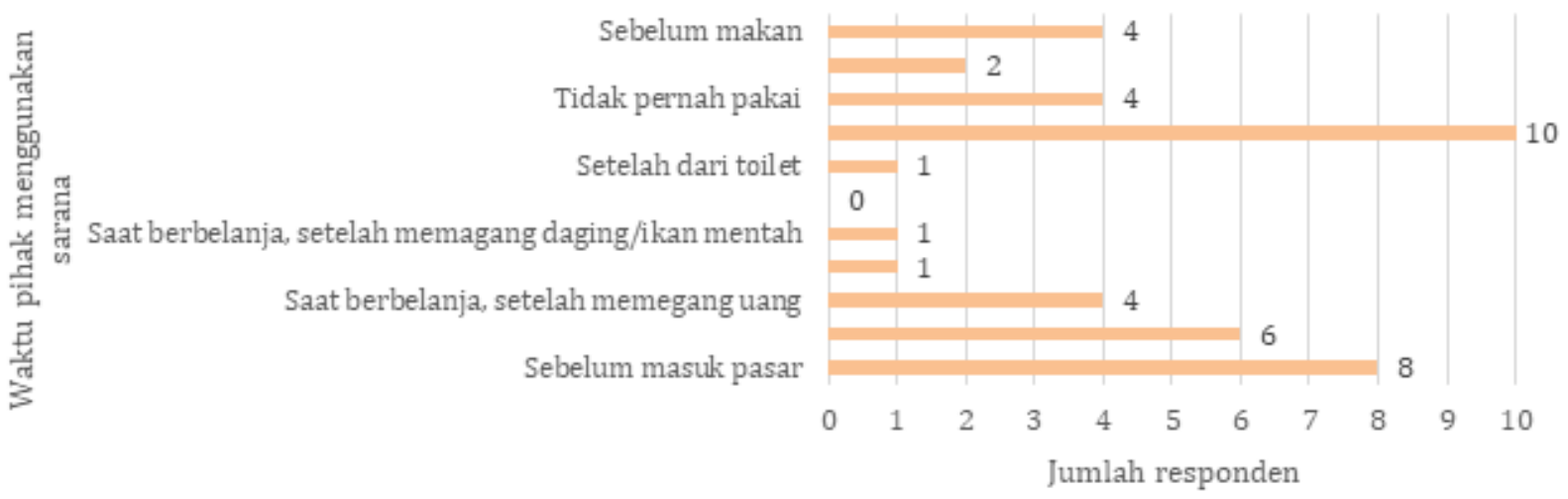

Pada saat monitoring, tim pengabdi mengevaluasi kondisi sarana cuci tangan yaitu kondisi dan kebersihan alat, ketersediaan air dan sabun, dan poster cuci tangan. Kondisi dan kebersihan alat serta ketersediaan air dan poster masih terjaga dengan baik, namun wadah sabun cair nampak kosong. Penilaian dari perwakilan responden sebanyak 5 orang menunjukkan bahwa kondisi sarana cuci tangan yang secara umum adalah baik (Gambar 6). Lebih dari 75\% mengungkapkan bahwa kondisi alat, kebersihan alat, dan ketersediaan air sudah baik sedangkan sisa dari perwakilan responden menganggapnya sudah cukup. Sebanyak $60 \%$ perwakilan responden mengatakan bahwa kondisi poster masih baik, 20\% diantaranya mengatakan bahwa kondisinya cukup dan sisanya mengatakan kondisinya sudah rusak karena sedikit mengelupas. Sebanyak $60 \%$ perwakilan responden mengatakan bahwa ketersediaan sabun tidak baik dan masih kurang sehingga perlu diperbaiki. Saat evaluasi, tim pengabdi menemukan bahwa terdapat kebocoran pada wadah sabun cuci tangan sehingga isinya cepat habis. Tim pengabdi telah mengganti wadah 
sabun cuci tangan dengan yang baru sehingga tidak bocor lagi. Secara umum, seluruh responden beranggapan bahwa sarana cuci tangan ini sangat bermanfaat untuk mencegah penyebaran COVID-19 di kalangan masyarakat setempat.

\section{Gambar 6}

Hasil Wawancara Terhadap Perwakilan responden $(n=5)$ mengenai kondisi sarana cuci tangan setelah 4 minggu pemasangan

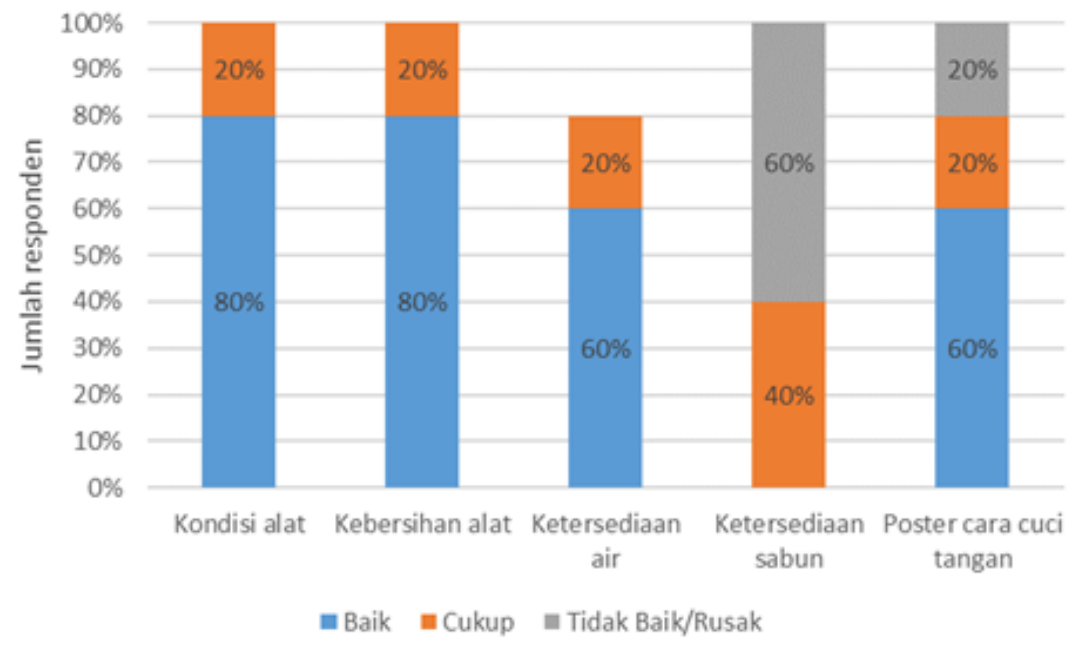

Seluruh pengunjung merasa bahwa pemasangan perangkat cuci tangan di Pasar Genteng sangat bermanfaat bagi pencegahan penyebaran COVID-19 di Pasar Genteng. Responden memberikan kritik dan saran berkaitan sarana. Sabun yang disediakan tempatnya bocor sehingga isinya cepat habis dan diganti dengan menaruh sabun batang dari salah satu penghuni. Namun, sabun batang membuat orang-orang risih karena dipakai dan dipegang banyak orang. Penempatan sarana sudah baik dan dapat dilihat banyak orang. Hal yang dapat ditingkatkan adalah jumlah sarana dan titik penempatan sarana agar jumlah orang yang memakai dapat lebih banyak. Selain itu, alat dapat dibuat lebih mencolok agar lebih banyak orang dapat melihat dan memakai sarana.

\section{KESIMPULAN DAN SARAN}

Kegiatan pengabdian masyarakat melalui penyediaan sarana cuci tangan sederhana di Pasar Genteng, Cisauk telah berlangsung dengan baik. Penyediaan sarana cuci tangan tersebut telah dirasakan manfaatnya oleh warga sekitar pasar, baik pengelola pasar maupun pengunjung pasar dan dapat meningkatkan kesadaran tentang pentingnya menjaga kebersihan diri dalam rangka pencegahan penyebaran COVID-19. Sarana cuci tangan tersebut masih dalam kondisi baik setelah 4 minggu dan tetap dapat digunakan setelah penggantian wadah sabun yang baru. Kesadaran masyarakat juga cukup baik yang terlihat dari inisiatif pengelola untuk menyediakan sabun batang ketika wadah sabun cair bocor. Pengisian sabun cair dapat menjadi hal yang sering dilupakan oleh pengelola pasar sehingga hal ini perlu menjadi catatan bagi tim untuk selalu mengingatkan pengelola pasar melalui ketua RT.

Kegiatan pengabdian ini telah berakhir namun demikian keberlanjutan pemanfaatan dan pemeliharaan sarana cuci tangan sederhana ini membutuhkan komitmen dari semua pihak yang meliputi tokoh masyarakat, pengelola, pedagang dan pengunjung pasar. Penulis mengharapkan sarana cuci tangan yang telah diberikan terus dipakai dan terus dimonitor agar jika terjadi kerusakan dapat langsung diperbaiki. Sabun juga sebaiknya rajin diisi ulang agar dapat digunakan. Penulis juga berharap sarana cuci tangan dapat terus membantu dalam upaya penghambatan penyebaran COVID-19 bagi masyarakat sekitar Pasar Genteng, Cisauk. 
Ucapan Terima Kasih (Acknowledgement)

Penulis mengucapkan terima kasih kepada Fakultas Teknobiologi Universitas Katolik Indonesia Atma Jaya atas hibah yang diberikan untuk keberlangsungan kegiatan pengabdian masyarakat ini. Penulis mengucapkan terima kasih kepada Pak Suherdi (ketua RT), Pak Atim (Pengelola Pasar) dan aktivis pemuda yang telah membantu terwujudnya kegiatan ini.

\section{REFERENSI}

CDC. (2020, Desember 7). Show me the Science - How to wash your hands. Centers for Disease Control and Prevention. https://www.cdc.gov/handwashing/show-me-the-sciencehandwashing.html.

CDC. (2020, November 24). When and how to wash your hands - Handwashing. Centers for Disease Control and Prevention. https://www.cdc.gov/handwashing/when-howhandwashing.html.

Chughtai, A. A., Seale, H., \& Macintyre, C. R. (2020). Effectiveness of cloth masks for protection against severe acute respiratory syndrome coronavirus 2. Emerging infectious diseases, 26(10). https://doi.org/10.3201/eid2610.200948.

Joniansyah. (2020, Maret 28). Sebaran COVID-19 di kabupaten Tangerang meluas, ini rinciannya. Teтро. https://nasional.tempo.co/read/1390630/lembaga-survei-ungkap-strategi-dulangsuara-di-pilkada-2020.

Kawahara, T., Akiba, I., Sakou, M., Sakaguchi, T., \& Taniguchi, H. (2018). Inactivation of human and avian influenza viruses by potassium oleate of natural soap component through exothermic interaction. PLoS ONE, 13(9). https://doi.org/10.1371/journal.pone.0204908.

Konda, A., Prakash, A., Moss, G. A., Schmoldt, M., Grant, G. D., \& Guha, S. (2020). Aerosol filtration efficiency of common fabrics used in respiratory cloth masks. ACS Nano, 14(5), 6339-6347. https://doi.org/10.1021/acsnano.0c03252.

Rizka, M. (2020, April 11). Inilah yang menentukan zona merah COVID-19 suatu daerah di Indonesia. Jabarnews.com https://jabarnews.com/read/84249/inilah-yang-menentukanzona-merah-COVID-19-suatu-daerah-di-indonesia/5.

Satgas Penanganan COVID-19 (2020, September 11). Peta sebaran COVID-19. Komite Penanganan Covid-19 dan Pemulihan Ekonomi Nasional. https://covid19.go.id/petasebaran.

WHO. (2020). Transmisi SARS-CoV-2: Implikasi terhadap kewaspadaan pencegahan infeksi. World Health Organization. https://www.who.int/.

WHO. (2020). Clean hands protect against infection. World Health Organization.

https://www.who.int/gpsc/clean_hands_protection/en/ 